\title{
Effect of excessive internet use in Saudi and Egyptian teenagers' health: Comparative study
}

\author{
Hoda M. Nafee*1, Boshra A. Mohammed ${ }^{1}$, Ahlam Y. Al-Hamdan ${ }^{2}$ \\ ${ }^{1}$ Mansoura University, Mansoura, Egypt \\ ${ }^{2}$ Fakeeh College for Medical Sciences, Jeddah, Saudi Arabia
}

Received: February 27, 2018

Accepted: March 28, 2018

Online Published: April 18, 2018

DOI: $10.5430 /$ jnep.v8n9p25

URL: https://doi.org/10.5430/jnep.v8n9p25

\begin{abstract}
Using of the internet today is a growing part of any society. Teenagers are the most users of the internet at their home and/or school. Therefore, it changes their daily lives in terms of physical, social, and psychological status that may exaggerated to be an internet addiction disorder or a physical problem. The aim of the study was to recognize the effects of excessive internet use in Saudi and Egyptian teenagers' health. The design used to conduct the present study was a descriptive correlation design, a convenient sample of 668 teenagers who were recruited from intermediate and secondary school from both countries, 331 teenagers from King Saudi Arabia (KSA) and 337 from Arab Republic of Egypt (ARE). Three tools were used for data collection: the first one was a questionnaire including demographic background of the participants and their families. The second was Internet Addiction Test (IAT) Young (1998) and the third pain rating scale to assess the intensity of musculoskeletal pain that encountered by the students. Results show that $86.6 \%$ of KSA teenagers used the internet daily compared to $69.6 \%$ in ARE. Regarding internet addiction, in teenagers, $0.9 \%$ were severe, $45.3 \%$ moderate and $47.7 \%$ mild compared to $0.3 \%, 46.3 \%$ and 44.2\% in ARE one, $67.3 \%$ of KSA teenagers have musculoskeletal pain with internet usage compared to $74.3 \%$ in ARE teenagers. No significant relation was found between both groups in relation to internet addiction. A significant relations were found in Saudi students' socio-demographic data and their level of internet addiction in the area of academic level $(p \leq .001)$, and level of academic achievement $(p=.037)$. No significant relation was found in the same area for Egyptian students. The researchers suggest further studies to be conducted in this field on larger sample size for both genders to identify the other factors related to excessive internet use.
\end{abstract}

Key Words: Excessive internet use, Internet addiction, Internet addiction disorders, Internet addiction test

\section{INTRODUCTION}

Adolescent usually, are between the ages of 11 and 18 years, they represent $20 \%$ of total population in King Saudi Arabia (KSA), ${ }^{[1]}$ while in Arab Republic of Egypt (ARE) was 19.1\% they find one's own identity and view of life and searching about their peers' acceptance. They develop a conflict with cultural, moral norms of society and authority; those conflicts can trigger a series of defense mechanisms to be receptive during this period and can become drawn to the Internet as a form of release. ${ }^{[2]}$

Nowadays, the internet is becoming an integral part of the daily life of the teenagers who are the most users of internet at home or school on a large scale and they are the first to begin experiencing problems associated with spending ever-increasing periods on the internet increases the risk of developing misuse, that referred in research literatures as

*Correspondence: Hoda M. Nafee; Email: hmelsayed@iau.edu.sa; Address: Mansoura University, Mansoura, Egypt. 
overuse of internet, problematical internet use and the maladaptive use of internet which is a recent and fast growing clinical phenomenon that may enhance psychiatric and psychosomatic symptoms of those age group. ${ }^{[3]}$ The other risk factor was widespread internet access that facilitates their using of favorite applications whenever and wherever they want, which increase the negative consequences neither in psychiatric as internet addiction or psychosomatic as musculoskeletal discomfort, such as back, neck, shoulder, and limb pain. ${ }^{[4,5]}$

The first studies conducted in this field were in the 90's, with the emergence of a new concept of internet addiction or cyberaddiction. Internet Addiction (IA) defined as the difficulty controlling ones impulses and the inability to disconnect from internet. ${ }^{[6]}$ Many studies asserted that the users of the internet should be aware of its positive and negative effects on their physical and psycho-social status, in spite of the various advantages of this technology as positive influences of the internet use of teenagers' cognitive abilities, creativity, improve their socialization, communication, problem solving, critical thinking skills in addition to improve language development, verbal and nonverbal skills, self-concept and used as a means to cope with stress. ${ }^{[7-11]}$

The Center of Health Protection of the Department of Health (CHPDH) summarized the negative effects of excessive use of internet and electronic devices on teenagers' health and development from the physical aspect as obesity, decreasing physical fitness, vision problems, musculoskeletal problems, sleep deprivation, injury and accidents or in psychosocial aspect as poor academic performance, worsing family relations, increasing sense of loneliness, depression, lowing self-steam and other mental health problems. ${ }^{[12]}$

Many researchers reported that the excessive use of the internet was associated with many social, psychological and physiological disorders. Regarding the excessive use of internet and teenagers' social health defect, some of the internet users spend longer periods of time connected and experience alienation, loneliness and depressive symptoms when offline. Besides, the preoccupied individuals with electronic games, search and recreational activities may be liable to neglect sporting and aerobic exercise, and familial communication as well as societal accomplishments. ${ }^{[13,14]}$ The Excessive use of social media and internet effects on children and adolescent's mental health status, brain development, physical and social development. ${ }^{[15]}$

In a study conducted in Jordan, a positive relation between anxiety, depression and occurrence of IA. The prevalence of Internet addiction was almost twice as high in boys (7\%) than girls $(4.2 \%)$. Also, the study indicated that Internet addiction had a significant relationship with poor sleep and depression. ${ }^{[16,17]}$ A study conducted in KSA found that $38.4 \%$ and $2.1 \%$ of the participants were categorized as moderate to severe internet addiction respectively, while $64.6 \%$ of them suffering from depression compared by $35.4 \%$ without depressive symptoms. ${ }^{[18]}$ In Egypt many studies found that $17 \%$ of teenagers used Facebook and $46 \%$ of them agreed that Facebook is an important part of their social life. A significant relation was found between IA score and social phobia and generalized anxiety in adolescent. Instead of a strong social bond from the use of the internet it may have catalyze undesired effects in cultural norms by shifting away from responsibilities and healthy social dynamism. ${ }^{[19,20]}$

Many researchers found that excessive use of the internet may affect physical health of the users and increase risk of somatic health problems, being associated with insufficient sleep among female adolescents and excessive weight among male adolescents, increased head flexion and neck flexion, increased lumbar lordosis, also headache and musculoskeletal pain. ${ }^{[21-23]}$ In Oman, many teenagers download internet content without awareness of its legality. This may effect on their lives and behavior in a negative way and had using mobile phones which exposes them to fatigue, headache, decreased concentration and local irritation and burning in their hands. ${ }^{[24]}$ As to an outright conviction about the Internet being a bane or boon to society at large, the topic remains highly controversial. Therefore, this study is of paramount importance because the study results will shed light on the effect of excessive internet use on teenagers' health in KSA and ARE.

\section{MATERIAls AND MethodS}

\subsection{Materials}

\subsubsection{Design}

A descriptive correlation design was used.

\subsubsection{Setting}

The study was conducted in 4 intermediate and secondary schools at 4 urban cities Jeddah and El-Dammam Cities in Saudi Arabia and El Zagazig and EL-Mansoura Cities in Egypt.

\subsubsection{Sample}

A convenient sample of 668 teenagers from both countries 331 from Saudi settings and 337 from Egypt represented the previous mentioned schools.

\subsubsection{Tools}

Three tools were used, the first tool consists of two parts in the forms of a questionnaire sheet that developed by the researchers based on the literatures reviewed. First part focus to assess socio demographic data of teenagers as age, gender, 
academic achievement and study level in addition to their families as fathers, mothers education level and monthly family income. Second part data related to internet uses, such as time, purpose and duration encountered by the students. ${ }^{[25]}$ Second tool was the Internet Addiction Test of Young (IAT) to assess the signs of internet addiction and its level that rating by five Likert scale $(\mathrm{Never}=1$, rarely $=2$, Sometimes $=3$, Often $=4$ and Always $=5) .{ }^{[26,27]}$ Third tool is the pain rating scale that scored from $0-10$ to assess the intensity of musculoskeletal pain.

\subsection{Methods}

The validity of the tools was ascertained by a jury of five experts in the nursing field (This was only for the first tool). The second tool was valid, according to Hawi (2013) ${ }^{[27]}$ who conducted a study regarding Arabic validation of the Internet Addiction Test (IAT).

A pilot study was carried out on 5 students from each school (a total of 20 students) to evaluate the tools applicability, clarity and to estimate the length of the time needed to fill the sheet.

Numeric pain rating: Explanation for the using of the numeric pain rating scale that matched to pain intensity if the number is zero on the scale it means "no pain", 10 means "worst possible pain", from 2 to 3 was mild, while moderate (4-6) and higher than 7 means severe pain.

Internet addiction scoring: A twenty questions related to internet addiction scored by a five Likert scale. The total grades of those questions were 100 points and categorized as: normal range (0-30 points), mild (31-49 points), moderate (50-79 points) and severe internet addiction from (80-100 points).

\subsection{Data collection}

An explanation of the study aim and how to complete all parts of the questionnaire was introduced to the students. Then the questionnaire was distributed to students during school activity hours, an informed consent was obtained from them, the questionnaires were collected at the end of school duty day. After collection of the questionnaire from the students, checking had been done to ensure that all parts were completed, and then it was coded.

Data were organized, revised, stored, tabulated and analyzed, using descriptive and inferential statistics with Statistical Package for Social Sciences (SPSS), version 21.0. A significant $p$ value of less than .05 was considered, for Chi-square test.

Published by Sciedu Press

\subsection{Ethical considerations}

An approval of ethical considerations was obtained from the Institution Review Board (IRB) of Doctor Soliman Fakeeh Hospital. An informed consent was obtained from students after the aim of the study was explained to them and they were informed that their participation is voluntarily. They were assured that the personal information kept confidential as the personal information weren't being linked directly with the results. Also to maintain the confidentiality of gathered data, it was collected anonymously and a code was assigned to each questionnaire sheet.

\section{Results}

Table 1 reveals that the majority of the Saudi students $82.8 \%$ were males, while in Egypt 59.1\% were females and their age median ranged between 16 and 15 years. Above two thirds of both Saudi and Egyptian students were living with their parents $(84.9 \%, 93.2 \%$ respectively). Regarding their academic level, $25.4 \%$ of Saudi students were in second intermediate school compared to $22.6 \%$ in Egypt. Concerning the level of students' academic achievement $45.4 \%$ of Saudi students were excellent compared to $27.3 \%$ in Egypt.

Table 1. Teenagers' socio-demographic data

\begin{tabular}{|c|c|c|}
\hline \multirow{2}{*}{ Variables } & Saudi Arabia $(\mathrm{n}=331)$ & Egypt $(n=337)$ \\
\hline & n (\%) & n (\%) \\
\hline \multicolumn{3}{|l|}{ Age in yrs. } \\
\hline Median (IQR) & $16.0(2)$ & $15.0(4)$ \\
\hline \multicolumn{3}{|l|}{ Gender } \\
\hline Male & $274(82.8)$ & $138(40.9)$ \\
\hline Female & $57(17.2)$ & $199(59.1)$ \\
\hline \multicolumn{3}{|c|}{ Arrangement the child among his brothers } \\
\hline $1^{\text {st }}$ & $74(22.5)$ & $119(36.4)$ \\
\hline $2^{\text {nd }}$ & $55(16.7)$ & $88(26.9)$ \\
\hline $3^{\text {rd }}$ & $81(24.6)$ & 45 (13.8) \\
\hline $4^{\text {th }}$ & $31(9.4)$ & $32(9.8)$ \\
\hline $5^{\text {th }}$ & $34(10.3)$ & $18(5.3)$ \\
\hline The last one & $50(15.2)$ & $28(8.6)$ \\
\hline The lonely & $6(18.1)$ & $7(2.1)$ \\
\hline \multicolumn{3}{|l|}{ Social status } \\
\hline Live with parents & $281(84.9)$ & $313(93.2)$ \\
\hline Live with mother & $25(7.6)$ & $15(4.5)$ \\
\hline Live with father & $17(5.1)$ & $6(1.7)$ \\
\hline Others & $8(2.4)$ & $3(0.9)$ \\
\hline \multicolumn{3}{|l|}{ Academic level } \\
\hline $1^{\text {st }}$ intermediate & $12(3.6)$ & $31(9.2)$ \\
\hline $2^{\text {nd }}$ intermediate & $84(25.4)$ & $76(22.6)$ \\
\hline $3^{\text {rd }}$ intermediate & $51(15.4)$ & $73(21.7)$ \\
\hline $1^{\text {st }}$ secondary & $69(20.8)$ & $16(4.7)$ \\
\hline $2^{\text {nd }}$ secondary & $77(23.3)$ & $9(2.7)$ \\
\hline $3^{\text {rd }}$ secondary & 38 (11.5) & $132(39.2)$ \\
\hline \multicolumn{3}{|c|}{ Level of academic achievement } \\
\hline Excellent & $150(45.4)$ & $92(27.3)$ \\
\hline Very good & $131(39.6)$ & $161(47.7)$ \\
\hline Good & $25(7.6)$ & $52(15.4)$ \\
\hline Average & $25(7.6)$ & $32(9.5)$ \\
\hline
\end{tabular}


Table 2 shows both fathers of Saudi and Egyptian students were nearly equal in their higher education level. The postgraduates were higher in Saudi fathers and mothers than in Egyptian one $(22.5 \%, 11.3 \%$ and $3.6 \%$ respectively). Regarding the fathers work, the majority of Saudi and Egyptian fathers were working $(92.0 \%$ and $82.2 \%)$. No work was registered in Saudi and Egyptian mothers $(73.1 \%, 69.3 \%$ respectively).

Table 2. Teenagers' family socio-demographic data

\begin{tabular}{|c|c|c|}
\hline \multirow{2}{*}{ Variables } & Saudi Arabia (n = 331) & Egypt $(n=337)$ \\
\hline & n (\%) & n (\%) \\
\hline \multicolumn{3}{|c|}{ Father's education level } \\
\hline Illiterate & $9(2.8)$ & $7(2.1)$ \\
\hline Primary & $29(8.9)$ & $12(3.6)$ \\
\hline Intermediate & 37 (11.4) & $59(17.5)$ \\
\hline Secondary & $82(25.2)$ & $152(45.1)$ \\
\hline Higher education & $95(29.2)$ & $95(28.2)$ \\
\hline Postgraduate & $73(22.5)$ & $12(3.6)$ \\
\hline \multicolumn{3}{|c|}{ Mother's education level } \\
\hline Illiterate & $42(12.7)$ & $31(9.2)$ \\
\hline Primary & $46(14.0)$ & $28(8.3)$ \\
\hline Intermediate & $40(12.2)$ & $56(16.6)$ \\
\hline Secondary & $76(23.2)$ & $149(44.2)$ \\
\hline Graduates & $90(27.4)$ & $61(18.1)$ \\
\hline Postgraduate & 37 (11.3) & $12(3.6)$ \\
\hline \multicolumn{3}{|c|}{ Does the father work? } \\
\hline Yes & $267(82.2)$ & $310(92.0)$ \\
\hline No & $64(19.3)$ & $27(8.0)$ \\
\hline \multicolumn{3}{|c|}{ Does the mother work? } \\
\hline Yes & 89 (26.9) & $104(30.9)$ \\
\hline No & $242(73.1)$ & $233(69.3)$ \\
\hline
\end{tabular}

Table 3 reveals that more than two thirds of Saudi and Egyp- tian students $(86.6 \%, 69.6 \%)$ use internet daily and $43.2 \%$ from Saudi staying online for more than 3 hours daily compared to $17.2 \%$ of Egyptian teenagers. Regarding the place of internet uses, above half of Saudi students $(60.1 \%)$ compared to $26.1 \%$ in Egyptian one used their bedroom, while $63.7 \%$ and $58.7 \%$ in both countries had no certain place. Regarding the purpose of the internet, in both groups above half of them used internet for social communication $(60.7 \%, 66.5 \%)$, while $56.1 \%$ was in Egyptian compared to $37.7 \%$ in Saudi students, were used for assistance in academic achievement \& studying.

Table 4 shows that musculoskeletal pain with internet uses, it appears that one third of both groups complained of moderate pain $(33.2 \%$ and $34.1 \%)$ respectively and the commonest sites of pain were hands and neck in both Saudi and Egyptian students $(22.1 \%, 20.5 \%$ and $19.9 \%, 18.7 \%)$ respectively and equal in head pain $(5.0 \%)$. The lowest other sites of pain were eye $(0.9 \%$ and $1.8 \%)$ respectively. Regarding the character of pain, the Saudi students' pain that grading from hotness then numbness was $38.1 \%$ and $16.3 \%$, while Egyptian students were throbbing followed by sharp $22.6 \%$ and $18.7 \%$ respectively.

Figure 1 illustrates levels of internet addiction where near half of Saudi and Egyptian students had mild and moderate internet addiction $(47.7 \%, 45.3 \%$, and $44.2 \%, 46.3 \%$ respectively). While severe IA was $0.9 \%$ in Saudi one compared to $0.3 \%$ in Egyptian students. No statistical significant relation was found between both groups in relation to internet addiction.

Table 3. Internet uses in both groups

\begin{tabular}{lll}
\hline Teenagers' nationality & $\begin{array}{l}\text { Saudi Arabia }(\mathbf{n}=\mathbf{3 3 1}) \\
\mathbf{n}(\mathbf{\%})\end{array}$ & $\begin{array}{l}\text { Egypt (n = 337) } \\
\mathbf{n}(\%)\end{array}$ \\
\hline Uariables & & $231(69.6)$ \\
Daily & $285(86.6)$ & $30(9.0)$ \\
Every two days & $20(6.1)$ & $24(7.2)$ \\
Every three days & $9(2.7)$ & $38(11.4)$ \\
Weekly & $12(3.6)$ & $14(4.2)$ \\
Others & $5(1.5)$ & $89(26.4)$ \\
Daily usage of internet in hours & & $68(20.2)$ \\
$<1$ hour & $46(13.9)$ & $58(17.2)$ \\
$1<3$ hours & $85(25.7)$ & $22(6.5)$ \\
3-5 hours & $143(43.2)$ & $88(26.1)$ \\
No certain time & $57(17.2)$ & $122(36.2)$ \\
Places of internet uses** & & $55(16.3)$ \\
Bedroom & $199(60.1)$ & $198(58.7)$ \\
Dining room & $88(26.6)$ & $189(56.1)$ \\
Outdoor & $150(45.3)$ & $111(32.9)$ \\
No certain place & $211(63.7)$ & $224(66.5)$ \\
Purpose of internet uses** & & $13(3.9)$ \\
Assistance in academic achievement\& studying & $125(37.7)$ & \\
Recreation \& employment of leisure time & $156(47.1)$ &
\end{tabular}


Table 4. Data related to musculoskeletal pain with internet uses in both groups

\begin{tabular}{|c|c|c|}
\hline $\begin{array}{ll}\text { Variables } & \text { Teenagers' nationality } \\
\end{array}$ & $\begin{array}{l}\text { Saudi Arabia (n = 331) } \\
\text { n (\%) }\end{array}$ & $\begin{array}{l}\text { Egypt }(n=337) \\
\text { n (\%) }\end{array}$ \\
\hline \multicolumn{3}{|l|}{ Musculoskeletal pain with internet uses } \\
\hline Yes & $246(74.3)$ & $227(67.3)$ \\
\hline No & $85(25.7)$ & $110(32.7)$ \\
\hline \multicolumn{3}{|l|}{ Severity of pain } \\
\hline Not constant & $19(5.7)$ & 73 (21.7) \\
\hline Mild & $127(38.4)$ & $71(18.1)$ \\
\hline Moderate & $80(24.2)$ & $72(21.4)$ \\
\hline Sever & $20(6.4)$ & $11(3.3)$ \\
\hline \multicolumn{3}{|l|}{ Sites of pain } \\
\hline Hands & 73 (22.1) & 67 (19.9) \\
\hline Neck & $68(20.5)$ & $61(18.7)$ \\
\hline Back & $61(18.4)$ & $43(12.8)$ \\
\hline Shoulders & $24(7.3)$ & $33(9.8)$ \\
\hline Head & $17(5.0)$ & $17(5.0)$ \\
\hline Other, as eye pain & $3(0.9)$ & $6(1.8)$ \\
\hline \multicolumn{3}{|l|}{ Characters of pain } \\
\hline Numbness & 54 (16.3) & 39 (11.6) \\
\hline Acute/sharp & $31(9.4)$ & $63(18.7)$ \\
\hline Throbbing & 35 (10.6) & 76 (22.6) \\
\hline Hotness & $126(38.1)$ & $49(14.5)$ \\
\hline
\end{tabular}

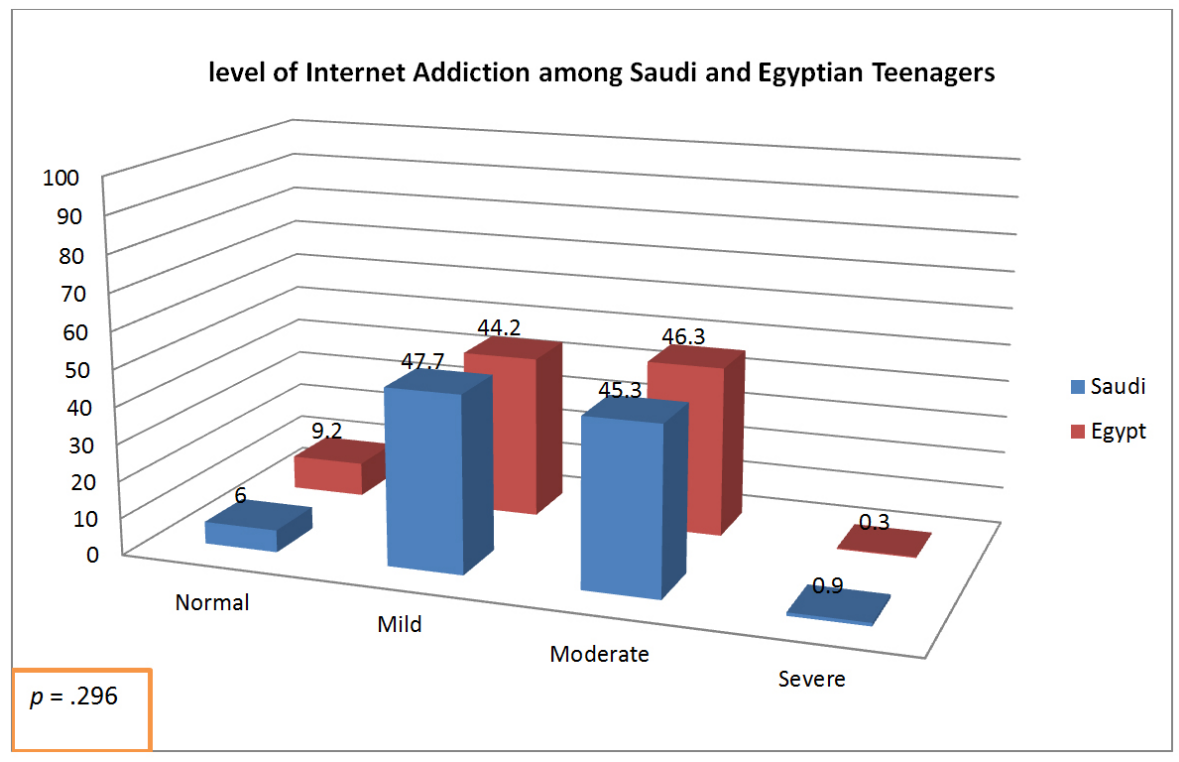

Figure 1. Percentage distribution of internet addiction among saudi and Egyptian students

Table 5 shows the distribution of different levels of the Internet Addiction by Saudi student's in relation to sociodemographic characteristics. Usage of the internet was similar among males and females $(p=.865)$. Also, there was no significant difference in the students' order among his/her brothers $(p=.564)$, and social status $(p=.075)$. Regarding Published by Sciedu Press the academic level of the students, the intermediate students were using the internet more than secondary students with statistically significant differences $(p \leq .001)$. In related with academic achievement, the most frequent internet users were achieved high level academic performance with statistically significant differences $(p=.037)$. 
Table 5. Correlations of Saudi students' socio-demographic data and level of internet addiction

\begin{tabular}{|c|c|c|c|c|c|}
\hline \multirow{2}{*}{ Internet addiction leve } & \multicolumn{4}{|c|}{ Addiction level( $n=331)$} & \multirow{2}{*}{$\begin{array}{l}\text { Test statistic \& } \\
p \text { value }\end{array}$} \\
\hline & $\begin{array}{l}\text { Normal } \\
(\mathrm{N}=20) \%\end{array}$ & $\begin{array}{l}\text { Mild } \\
(\mathrm{N}=158) \%\end{array}$ & $\begin{array}{l}\text { Moderate } \\
(\mathrm{N}=150) \%\end{array}$ & $\begin{array}{l}\text { Severe } \\
(N=3) \%\end{array}$ & \\
\hline \multicolumn{5}{|l|}{ Gender } & \multirow{3}{*}{$\begin{array}{l}\text { Chi-square }=0.736 \\
p=.865\end{array}$} \\
\hline Male & $16(5.8)$ & $131(47.8)$ & $124(45.3)$ & $3(1.1)$ & \\
\hline Female & $4(7.0)$ & $27(47.4)$ & $26(45.6)$ & 0 & \\
\hline \multicolumn{5}{|c|}{ Arrangement the child among his brothers } & \multirow{8}{*}{$\begin{array}{l}\text { Chi-square }=16.412 \\
p=.564\end{array}$} \\
\hline First & $6(8.1)$ & $35(47.3)$ & $31(41.9)$ & $2(2.7)$ & \\
\hline Second & $5(9.1)$ & $26(47.3)$ & $23(41.8)$ & $1(1.8)$ & \\
\hline Third & $5(6.2)$ & $35(43.2)$ & $41(60.6)$ & 0 & \\
\hline Fourth & $2(6.5)$ & $18(58.1)$ & $11(35.5)$ & 0 & \\
\hline Fifth & 0 & $17(50.0)$ & $17(50.0)$ & 0 & \\
\hline The last & $2(4.0)$ & $22(44.0)$ & $26(52.0)$ & 0 & \\
\hline The only & 0 & $5(83.3)$ & $1(16.7)$ & 0 & \\
\hline \multicolumn{6}{|l|}{ Social status } \\
\hline Live with parents & $15(5.3)$ & $143(50.9)$ & $120(42.7)$ & $3(1.1)$ & \multirow{4}{*}{$\begin{array}{l}\text { Chi-squa } \\
p=.075\end{array}$} \\
\hline Live with mother & $3(15.0)$ & $4(20.0)$ & $18(65.0)$ & 0 & \\
\hline Live with father & $2(11.8)$ & $5(29.0)$ & $10(58.8)$ & 0 & \\
\hline Others & 0 & $6(75.0)$ & $2(25.0)$ & 0 & \\
\hline \multicolumn{5}{|l|}{ Academic level } & \multirow{7}{*}{$\begin{array}{l}\text { Chi-square }=42.340 \\
p \leq .001 * *\end{array}$} \\
\hline First intermediate & $4(33.3)$ & $3(25.0)$ & $5(41.7)$ & 0 & \\
\hline Second intermediate & 0 & $39(46.4)$ & $44(52.4)$ & $1(1.2)$ & \\
\hline Third intermediate & $5(9.8)$ & $20(39.2)$ & $24(47.1)$ & $2(3.9)$ & \\
\hline First secondary & $5(7.2)$ & $30(43.5)$ & $34(49.3)$ & 0 & \\
\hline Second secondary & $1(1.3)$ & $47(61.0)$ & $29(37.7)$ & 0 & \\
\hline Third secondary & $5(13.2)$ & $19(50.0)$ & $14(36.8)$ & 0 & \\
\hline \multicolumn{5}{|c|}{ Level of academic achievement } & \multirow{5}{*}{$\begin{array}{l}\text { Chi-square }=17.865 \\
p=.037^{*}\end{array}$} \\
\hline Excellent & $9(6.0)$ & $73(48.7)$ & $67(44.7)$ & $1(0.7)$ & \\
\hline Very good & $4(3.1)$ & $59(45.0)$ & $66(50.4)$ & $2(1.5)$ & \\
\hline Good & $6(24.0)$ & $13(52.0)$ & $6(24.0)$ & 0 & \\
\hline Average & $1(4.0)$ & $13(52.0)$ & $11(44.0)$ & 0 & \\
\hline
\end{tabular}

Table 6 shows the distribution of different levels on the Internet addiction scale by the Egyptian student's in relation to socio-demographic characteristics. A statistical significant difference in gender where $(p=.051)$, arrangement of the students' among his/her brothers $(p=.855)$, social status ( $p$ $=.481)$, academic level $(p=.109)$, and level of academic achievement $(p=.065)$.

\section{Discussion}

Teenagers are at a higher risk to develop IA due to their $\operatorname{cog}-$ nitive immaturity, the physiological, psychological changes in addition to their academic needs and stresses that make them unable to control the time spent online. ${ }^{[28,29]}$

The relation between internet-related activities and self-rated health complaints has become a public health concern, where adolescents' internet-use time has increased. While on the other hand their physical activity has decreased, resulting in musculoskeletal problems. ${ }^{[30]}$

According to the data of the present study, students' median age in both groups ranged from 15 to 16 years and the majority of Saudi teenagers were males $(82.8 \%)$ while females participated $59.1 \%$ in Egyptian teenage. Regarding using the internet, academic achievement was $37.7 \%$, social communication $(60.7 \%)$ and entertainment $(66.5 \%)$ in both groups. These finding in accordance with Karacic (2017) who found that the highest level of internet addiction was found among the adolescents aged 15-16 years due to their greater level of independence, their free time and social activities are less controlled by their parents. They used internet for school/work (20.2\%) and entertainment (11.9\%). ${ }^{[31]}$ Other study done by Miao (2017) ${ }^{[32]}$ found that Social networking, school work, entertainment, gaming and shopping ranked as the top five among all the online activities. 
Table 6. Correlations of Egyptian students' socio-demographic data and their level of internet addiction

\begin{tabular}{|c|c|c|c|c|c|}
\hline \multirow{2}{*}{$\begin{array}{l}\text { Internet Addiction Level } \\
\text { Variables }\end{array}$} & \multicolumn{4}{|c|}{ Addiction level $(n=337)$} & \multirow{2}{*}{$\begin{array}{l}\text { Test statistic } \\
\& p \text { value }\end{array}$} \\
\hline & $\begin{array}{l}\text { Normal } \\
(\mathrm{N}=31) \%\end{array}$ & $\begin{array}{l}\text { Mild } \\
(N=149) \%\end{array}$ & $\begin{array}{l}\text { Moderate } \\
(\mathrm{N}=156) \%\end{array}$ & $\begin{array}{l}\text { Severe } \\
(N=1) \%\end{array}$ & \\
\hline Gender n (\%) & & & & & Chi-square $=$ \\
\hline Male & $7(5.1)$ & $58(42.0)$ & $72(52.2)$ & $1(0.7)$ & 0.767 \\
\hline Female & $24(12.1)$ & $91(45.7)$ & $84(42.2)$ & 0 & $p=.051$ \\
\hline \multicolumn{6}{|l|}{ Arrangement the child among his brothers } \\
\hline First & $10(8.4)$ & $58(48.7)$ & 51 (42.9) & 0 & \multirow{7}{*}{$\begin{array}{l}\text { Chi-square }= \\
11.849 \\
p=.855\end{array}$} \\
\hline Second & $10(11.4)$ & $31(35.2)$ & 46 (52.3) & $1(1.1)$ & \\
\hline Third & $4(8.9)$ & $20(44.4)$ & $21(46.7)$ & 0 & \\
\hline Fourth & $2(6.2)$ & $15(46.9)$ & 15 (46.9) & 0 & \\
\hline Fifth & $2(11.1)$ & $8(44.4)$ & $8(44.4)$ & 0 & \\
\hline The last & $3(10.7)$ & $15(53.6)$ & 10 (35.7) & 0 & \\
\hline The only family & 0 & $2(28.6)$ & $5(71.4)$ & 0 & \\
\hline \multicolumn{6}{|l|}{ Social status } \\
\hline Live with parents & $31(9.9)$ & $135(43.1)$ & $146(46.6)$ & $1(0.3)$ & \multirow{4}{*}{$\begin{array}{l}\text { Chi-square }= \\
8.534 \\
p=.481\end{array}$} \\
\hline Live with mother & 0 & 7 (46.7) & $8(53.3)$ & 0 & \\
\hline Live with father & 0 & $4(66.7)$ & $2(33.3)$ & 0 & \\
\hline Others & 0 & $3(100)$ & 0 & 0 & \\
\hline \multicolumn{6}{|l|}{ Academic level } \\
\hline First intermediate & $9(29.0)$ & 10 (32.3) & 11 (35.5) & $1(3.2)$ & \multirow{6}{*}{$\begin{array}{l}\text { Chi-square }= \\
21.970 \\
p=.109\end{array}$} \\
\hline Second intermediate & $8(3.1)$ & $33(45.0)$ & $35(50.4)$ & 0 & \\
\hline Third intermediate & $8(16.0)$ & $31(52.0)$ & $34(32.0)$ & 0 & \\
\hline First secondary & $3(18.8)$ & $7(43.8)$ & $6(37.5)$ & 0 & \\
\hline Second secondary & $3(33.3)$ & $3(33.3)$ & $3(33.3)$ & 0 & \\
\hline Third secondary & 0 & $65(49.2)$ & $67(50.8)$ & 0 & \\
\hline \multicolumn{6}{|l|}{ Level of academic achievement } \\
\hline Excellent & $11(12.0)$ & $35(38.0)$ & $46(50.0)$ & 0 & \multirow{4}{*}{$\begin{array}{l}\text { Chi-square }= \\
16.099 \\
p=.065\end{array}$} \\
\hline Very good & $14(8.7)$ & $68(42.2)$ & 79 (49.1) & 0 & \\
\hline Good & 3 (5.8) & $30(57.7)$ & 19 (36.5) & 0 & \\
\hline Average & $3(9.4)$ & $16(50.0)$ & 12 (37.5) & 1 (3.1) & \\
\hline
\end{tabular}

According to literature, values used as reference points to characterize long electronic devices use time varies between 2 and 5 hours/day. ${ }^{[33]}$ Many studies found a positive relation between daily prolonged time use of internet and teenagers' internet addiction. And their clarification of causes that keep teenagers risky were inability to restrict their time online, especially when they engage in chat and community websites, and the availability of 24-hour internet service at homes. ${ }^{[19,34,35]}$

The prolonged use of internet more than $3 \mathrm{hrs}$./day leads to internet overuse (Gamitoa 2016). ${ }^{[36]}$ The previous above mentioned studies incongruent with our study, where $86.6 \%$ of Saudi teenagers used the internet daily with $43.2 \%$ of them saying online from 3 to more than $5 \mathrm{hrs}$./daily, compared to $69.6 \%$ and $17.2 \%$ in Egyptian, that reflect elevation of IA among Saudi teenagers than in Egyptian one.

The availability of numerous devices could be associated

Published by Sciedu Press with a higher probability of internet access at any time and any place and away from parental control especially at teenagers' bedroom that had a positive relation to excessive internet usage and sleep problems, ${ }^{[37,38]}$ those results in similarity with the present study where IA was higher in Saudi teenagers $60.1 \%$ had internet access in their bedroom and $63.7 \%$ used it anywhere away from their parents control compared to $26.1 \%$ and 58.7 in Egyptian teenagers (see Table 3). The prevalence of IA in Asian countries was relatively higher than the prevalence reported in Europe and in the Middle Eastern. ${ }^{[39,40]}$

The rapid growth of internet users in middle east exceeding and IA was $80 \%$ in some countries. ${ }^{[41]}$ A survey done in KSA and ARE (2007) ${ }^{[42]}$ showed that $54.6 \%$ from teenagers in both countries had IA. Also Pallanti et al. (2006) ${ }^{[43]}$ his study revealed that IA was $51.6 \%$. Recently in KSA Al-hantoushi and Al-abdullateef (2014) $)^{[34]}$ found that the prevalence of IA was 50.7\%). In Egypt, Reda et al. (2012) ${ }^{[19]}$ found that 
$22.1 \%$ of teenagers have a problematic internet use, and $8 \%$ proved to have internet addiction.

The above previous mentioned studies support and in covenant with the present study where internet overuse increased to be $94 \%$ in Saudi students compared to $88 \%$ the Egyptian one. Regarding the categories of IA according to IAT the present study estimated that near half of Saudi and Egyptian students had mild and moderate internet addiction $(47.7 \%, 45.3 \%$, and $44.2 \%, 46.3 \%)$ respectively, while $0.9 \%$ was severe in Saudi one compared to $0.3 \%$ in Egyptian. Those results were incongruent with Dawood et al. $(2015)^{[44]}$ who found that $55.3 \%$ of Saudi students had average internet users. While $40.3 \%$ occasional or frequent internet related problems and only $4.4 \%$ of the participants experienced significant internet related problems. And also the study done by Srijampana et al. (2014) ${ }^{[45]}$ revealed that $64.4 \%$ were average users, $11.8 \%$ as possible addicts, and $0.4 \%$ as addicts.

A variety of physical problems are also associated with frequent internet use, including carpal tunnel syndrome, dry eyes, headaches, musculoskeletal complaints and pain or visual fatigue Anderson 2001. ${ }^{[46]}$ The study of American youth found a relationship between time spent at a computer and musculoskeletal discomfort that is described as musculoskeletal pain. Computer use is an important risk factor for children's health, because neck/shoulder and back pain in adolescence may result in early onset of musculoskeletal degenerative dysfunction (Hope et al.). ${ }^{[47]}$ Hakala (2006), and Gur, Sisman, Sener et al. $(2016)^{[48,49]}$ found that teenagers whom sit on the internet for a long time experienced pain in the back, neck and arm, constipation, gas formation and eye tearing or redness.

Another two studies done by Saueressig et al. (2015) ${ }^{[50]}$ and Derbyshire et al. (2013) ${ }^{[51]}$ found that a significant relation between musculoskeletal pain complaints in both teenagers' genders and use of computers for more than 3 hours daily. In addition to physical activities, which improve musculoskeletal function and avoid muscle stiffness with excessive use of internet, it was malfunctioning and increasing the pain intensity. The results are incongruent with the present study where the majority of both groups had musculoskeletal pain.

Regarding the relation between teenager's sociodemographic data variables and IA, in the current study there was no statistical significant relation between IA and gender of teenagers' internet users in Saudi group but had a significant relation in Egyptian one where the females had more IA than males. This results in agreement with Sasmaz et al. (2014) ${ }^{[52]}$ who found no significant relation between gender and IA, while Rucker et al. (2015) ${ }^{[53]}$ found that the females had IA more than males but disagree with Koyuncu et al. (2014) ${ }^{[54]}$ where males had IA than females.

The present study shows a statistical significant relation between IA and academic level where the intermediate school students were the highest internet users than secondary school students only in Saudi group and this result in corresponding with Sasmaz et al. (2014) ${ }^{[52]}$ and Wu et al. (2016) ${ }^{[55]}$ where the IA increased among the lowest level of secondary school compared to the highest level. The internet is considered as an indicator of social and educational class, in the present study the IA was higher in Saudi group rather than the Egyptian one, where the Saudi students $22 \%$ of their fathers had a postgraduates level of education compared to 3.6\% in Egyptian one (see Table 2). This result is consistent with Lam et al. (2009) ${ }^{[56]}$ who found that IA was higher in teenagers whom their parents hold a university or higher education, this may be due to the more access of internet than the other groups.

The previous result in contrary with Tekkant \& Topalglu (2015), ${ }^{[57]}$ results that reflected higher IA in students whose fathers were primary-secondary school graduates. Also the current study found that IA was higher in Saudi group than the Egyptian one where the Saudi students, $27.4 \%$ and $11.3 \%$ of their mothers who are graduates and postgraduates level of education, compared to $18.1 \%$ and $3.6 \%$ in Egyptian one (see table 2). This result is consistent with Tekkant and Topalglu (2015) ${ }^{[57]}$ and Koyuncu et al. (2014) ${ }^{[54]}$ while inconsistent with Malak et al. (2017). ${ }^{[16]}$ Who found the prevalence of IA was higher in students whose mothers' educational level was a secondary graduate.

The current study revealed that the most users of internet in Saudi group were achieved high level of academic performance with statistically significant differences (see Table 5) and this result in disharmony with Malak et al. 2017; ${ }^{[16]}$ Al-hantoushi \& Al-abdullateef (2014) ${ }^{[34]}$ whom found that students with poor academic performance had higher levels of IA. On the other hand the Egyptian group had no statistical relation between level of academic performance and IA and this result in agreement with Hawi (2012) ${ }^{[58]}$ who found that no relation between level of academic performance and IA.

Parents play an important role in teenagers' life and many studies found that a single parent was a risk factor of IA, particularly for those living with the father only Jablonska \& Lindberg (2009) ${ }^{[59]}$ and Wang et al. (2016), ${ }^{[60]}$ but was less in those whom live with their mothers due to the more exercise of control and maternal influences are stronger than that of paternal influences (Shek 1998). ${ }^{[61]}$ The above mentioned three studies in harmony with this study where the percentage of IA was highest in Saudi students whom live with their 
fathers than their mothers (see Table 5), while the IA decrease in Egyptian students where the majority of them live with their parents (see Table 6). Further research is required to address different risk factors for internet addiction.

\subsection{Limitation of the study}

The current study is not without limitation, using a convenience sampling technique affected the generalizability of the study results to specific geographic regions in both countries and data collection was based on self-reported questionnaires which are prone to recall bias.

\subsection{Recommendation and suggestions}

Based on the results of the present study, the researchers suggest further studies to be conducted in this field on a larger sample size for both genders to identify the other factors related to creating Excessive Internet Use. School specialists and parents pay more attention to their teenagers to identify the internet addiction signs and the balance between the internet use, academic study and social life. An intensive awareness program to be prepared targeting school specialists and parents regarding the adverse effect of internet use on children and how to deal with it. Students should be oriented to negative issues of excessive use of the internet that may effect on their health, social and family relationships.

\section{Conclusion}

The present study provided useful information about internet addiction among Saudi and Egyptian school students to address this problem. Near half of participants had mild and moderate internet addiction. There is no statistically significant relation was found between both groups in relation to IA. Also it shows the majority of both groups had musculoskeletal pain also it shows a statistically significant relation between IA and academic level where the intermediate school students were the highest internet users than secondary school students in Saudi group.

\section{BIO STATEMENT}

Hoda M. Nafee PhD is lecturer of pediatric nursing, College of Nursing, Mansoura University, Egypt. She also is an Assistant Professor in fundamental of nursing Department, at College of Nursing, Imam Abdulrahman Bin Faisal University (ex Dammam) KSA.

Boshra A. Mohammed $\mathrm{PhD}$ is lecturer of pediatric nursing, College of Nursing, Mansoura University, Egypt.

Ahlam Yousif Al-Hamdan is Professor of Psychiatric and Mental Health Nursing Fakeeh College for Medical Sciences, Jeddah, KSA.

\section{CONFLiCTS OF INTEREST Disclosure}

The authors declare that there is no conflict of interest.

\section{REFERENCES}

[1] AlBuhairan F, Olsson T. Advancing adolescent health and health services in Saudi Arabia: exploring health-care providers' training, interest, and perceptions of the health-care needs of young people. Advances in Medical Education and Practice. 2014; 5: 281. PMid:25214805

[2] UNICEF. Children in Egypt: a statistical digest, UNICEF Egypt, Cairo; 2015.

[3] Tsisika A, Critselis E, Louizou A, et al. Determinants of internet addiction among adolescents: A case-control study. The Scientific World Journal. 2011; 11: 866-874.

[4] Lenhart A, Purcell K, Smith A, et al. Social media \& mobile Internet use among teens and young adults. PEW Internet and American Life Project. Washington, D. C.: Pew Research Center; 2012.

[5] Jacobs K, Hudak S, McGiffert J. Computer-related posture and musculoskeletal discomfort in middle school students. Work. 2009; 32: 275-283. PMid:19369720

[6] Young K. Internet addiction: The emergence of a new clinical disorder. Cyber Psychology and Behavior. 1998; 1: 237-244. https : //doi.org/10.1089/cpb.1998.1.237

[7] Poushter J, Bell J, Oates R. Internet seen as positive influence on education but negative on morality in emerging and developing nations. Pew Research Center; 2015.

Published by Sciedu Press
[8] O'Keeffe G, Clarke-Pearson K. The impact of social media on children, adolescents, and families. Pediatrics. 2011; 127(4).

[9] Quarshie H. The level of use of computer and the internet by teenage girls in Ghana. Journal of Emerging Trends in Computing and Information Sciences. 2012; 3(8): 1253-1257.

[10] Raheel H. Coping strategies for stress used by adolescent girls in Riyadh, Kingdom of Saudi Arabia. Pakistan Journal of Medical Sciences. 2014; 30(5): 958-62. PMid:25225507

[11] Guana S. Subrahmanyam k. Youth internet use: risks and opportunities. Current Opinion in Psychiatry. 2009; 22(4): 351-356. PMid:19387347 https://doi.org/10.1097/YCD.0b013e3283 $2 \mathrm{bd} 7 \mathrm{e} 0$

[12] Department of Health. The Government of the Hong Kong special administrative region. Report of advisory group on health effects of use of internet and electronic screen products. 2015.

[13] Hellström C, Nilsson K, Leppert J. Effects of adolescent online gaming time and motives on depressive, musculoskeletal, and psychosomatic symptoms. Upsala Journal of Medical Sciences. 2015; 120(4).

[14] Kim J, Hui H, Lau C, et al. Brief report: predictors of heavy internet use and associations with health promoting and health risk behaviors among Hong Kong university students. Journal of Adolescence. 2010; 33(1): 215-220. PMid:19427030 https ://doi.org/10.1016/j. adolescence.2009.03.012 
[15] Atoum A, Al-Hattab L. Internet addiction and its relation to psychosocial adaptation among Jordanian high basic stage students. Journal of Psychology and Behavioral Science. 2015; 3(1): 96-104.

[16] Malak Z, Khalifeh A, Shuhaiber H. Prevalence of internet addiction and associated risk factors in Jordanian school students. Journal of Computers in Human Behavior. 2017; 70: 556-563.

[17] Abdrbo A, Hassanein S. Effect of internet use for health information and internet addiction on adolescents' female high school health lifestyle. Journal of Nursing Education and Practice. 2017; 7(12): 10-19. https://doi.org/10.5430/jnep.v7n12p10

[18] Khalil A, Alharbi N, Alhawasawi H, et al. Prevalence of internet addiction among nursing students and the association with their academic performance and mental health. Athens Journal of Health 2016; 3(4): 291-306.

[19] Reda M, Rabie M, Mohsen N, et al. Problematic internet users and psychiatric morbidity in a sample of Egyptian adolescents. Journal of Psychology. 2012; 3(8): 626-631.

[20] El Gazzar N. Adolescents' perception and attitudes towards social media networks in Egypt-A Survey. 2011.

[21] Richard E, Akre B, Berchtold A, et al. A U-Shaped association between intensity of internet use and adolescent health advertising disclaimer. Pediatrics. 2011; 127(2).

[22] Punamaki R, Wallenius M, Nygard C, et al. Use of information and communication technology (ICT) and perceived health in adolescence: the role of sleeping habits and waking-time tiredness. Journal of Adolescents. 2007; 30(4): 569-85. PMid:16979753 https://doi.org/10.1016/j .adolescence.2006.07.004

[23] Surisa J, Akre C, Pigueta C, et al. Is internet use unhealthy? A crosssectional study of adolescent internet overuse. Swiss Medical Weekly. 2014; 144: 14061.

[24] Al-Badi A, Al Mahrouqi S, Ali O. The Influence of the internet on teenagers' behavior in Oman. Journal of Internet Social Networking \& Virtual Communities. 2016.

[25] McCaffery M, Beebe A. Pain: Clinical manual for nursing practice. 2nd ed. Mosby St. Louis, MO; 1989.

[26] Young K, de Abreu C. Internet Addiction: A handbook and Guide to Evaluation and Treatment. Hoboken, NJ: John Wiley \& Sons, Inc; 2011.

[27] Hawi N. Arabic Validation of the Internet Addiction Test. Cyberpsychology, Behavior and Social Networking. 2013; 16(3): 200-204 PMid:23441685 https://doi.org/10.1089/cyber.2012.042 6

[28] Leung L. Stressful life events, motives for internet use and social support among digital kids. Cyberpsychology and Behavior. 2014; 10(2): 204-214. PMid:17474837 https ://doi .org/10.1089/cp b. 2006.9967

[29] Liu C, Liao M, Smith D. An empirical review of internet addiction treatment outcome studies in China. Research on Social Work Practice. 2012; 22(3): 282-292. https : //doi.org/10.1177/104973 1511430089

[30] Madeleine P, Vangsgaard S, Hviid Andersen J, et al. Computer work and self-reported variables on anthropometrics, computer usage, work ability, productivity, pain, and physical activity. BMC Musculoskeletal Disorders. 2013; 14: 226. PMid:23915209 https : //doi.org/10.1186/1471-2474-14-226

[31] Karacic S, Oreskovic S. Internet addiction through the phase of adolescence: a questionnaire study. JMIR Mental Health. 2017; 4(2): e11. PMid:28373154 https://doi.org/10.2196/mental.5537

[32] Miao X, Jiang X, Wang P, et al. Prevalence of internet addiction and risk factors related to family and school among adolescents in China. Addictive Behaviors Reports. 2018; 7: 14-18. PMid:29450251 https://doi.org/10.1016/j.abrep.2017.10.003
[33] Barbosa Filho VC, De Campos W, Lopes Ada S. Epidemiology of physical inactivity, sedentary behaviors, and unhealthy eating habits among Brazilian adolescents: a systematic review. Ciênc Saude Colet. 2014; 19(1): 173-93. PMid:24473615 https ://doi .org/10.159 0/1413-81232014191.0446

[34] Al-hantoushi M, Al-abdullateef S. Internet addiction among secondary school students in Riyadh city, its prevalence, correlates and relation to depression: A questionnaire survey. International Journal of Medical Science and Public Health. 2014; 3(1): 10-15. https://doi .org/10.5455/ijmsph.2013.130920131

[35] Zboralski K, Orzechowska A, Talarowska M, et al. The prevalence of computer and internet addiction among pupils. Postepy Hig Med Dosw. 2009; 63: 8-12.

[36] Gamitoab P, Morais D, Ovivera J, et al. Frequency is not enough: Patterns of use associated with risk of internet addiction in Portuguese adolescents. Computers in Human Behavior. 2016; 28: 471-478.

[37] Ko CH, Yen JY, Chen CC, et al. Proposed diagnostic criteria of Internet addiction for adolescents. J Nerv Ment Dis. 2005; 193: 728-733. https://doi.org/10.1097/01.nmd.0000185891.13719.54

[38] Ha YM, Hwang WJ. Gender Differences in Internet Addiction Associated with Psychological Health Indicators among Adolescents Using a National Web-based Survey. International Journal of Mental Health and Addiction. 2014; 12: 660-669. https://doi .org/10 .1007/s11469-014-9500-7

[39] Canan F, Ataoglu A, Nichols L, et al. Evaluation of psychometric properties of the internet addiction scale in a sample of Turkish high school students. Cyberpsychology, Behavior and Social Networking. 2010; 13(3): 317-320

[40] Mak K, Lai C, Watanabe H, et al. Epidemiology of internet behaviors and addiction among adolescents in six Asian countries. Cyber Psychology Behavior and Social Networking. 2014; 17(11): 512-523. PMid:24950260

[41] Missaoui S, Brahim T, Bouriga W, et al. Prevalence and consequences of internet addiction in a cohort of Tunisian adolescents: A Pilot Study. Journal of Child and Adolescent Behavior. 2015; 3: 23754494.

[42] Ismail B. Internet addiction and its relationship to personality dimension, psychological disorder for teens. Journal of Educational Faculty, Zagazig University. 2007; 55: 33-96.

[43] Pallanti S, Bernardi S, Leonardo Q. The shorter PROMIS questionnaire and the internet addiction scale in the assessment of multiple addictions in a high-school population: prevalence and related disability. CNS Spectrums. 2006; 11(12): 966-74. https: //doi.org/10.1017/S1092852900015157

[44] Dawood M, Mitsu R, Monica A. Patterns of Internet Use among Saudi Public Adults: A Cross Sectional Study. Journal of Health, Medicine and Nursing. 2015; 13: 11-18.

[45] Raju Srijampana V, Endreddy A, Prabhath K, et al. Prevalence and Patterns of internet addiction among medical students. Medical Journal of Dr.D.Y. Patil Vidyapeeth University. 2014; 7: 709-713.

[46] Anderson KJ. Internet use among college students: an exploratory study. J Am Call Health. 2001; 50: 21-26. PMid:11534747 https : //doi.org/10.1080/07448480109595707

[47] Hope M, Cumming M. Elizabeth A, et al. Relation of Adolescent Video Game Play to Time Spent in Other Activities. Archives of Pediatrics \& Adolescent Medicine. 2007; 161: 684-689.

[48] Hakala P, Rimpelä A, Saarni L, et al. Frequent computer-related activities increase the risk of neck - shoulder and low back pain in adolescents. European Journal of Public Health. 2006; 16(5): 536541. https://doi.org/10.1093/eurpub/ckl025 
[49] Gur K, Sisman F, Sener N, et al. Internet addiction in Turkish adolescents and their postponed activities of daily living. Journal of Health Sciences of Kocaeli University. January 2016; 2(1): 32-38.

[50] Saueressig I, Oliveira V, Xavier M, et al. Prevalence of musculoskeletal pain in adolescents and its association with the use of electronic devices. Rev Dor. 2015; 16(2): 129-35.

[51] Derbyshire K, Lust K, Schreiber L, et al. Problematic Internet use and associated risks in a college sample. Comprehensive Psychiatry. 2013 July; 54(5): 415-422. https ://doi.org/10.1016/j . comp psych.2012.11.003

[52] Sasmaz T, Oner S, Kurt A, et al. Prevalence and risk factors of Internet addiction in high school students. European Journal of Public Health. 2014; 24(1): 15-20. https : //doi .org/10.1093/eurpub /ckt051

[53] Rücker J, Akre C, Berchtold A, et al. Problematic Internet use is associated with substance in young adolescents. Acta Paediatrica. 2015 May; 14(5): 504-507. https ://doi.org/10.1111/apa.12971

[54] Koyuncu T, Unsal A, Arslantas D. Assessment of internet addiction and loneliness in secondry and hifh school students. JAMA. The Journal of the Pakistan Medical Association. 2014 Sep; 64(9): 998-1002.
[55] Wu C, Wong H, Yu K, et al. Parenting approaches, family functionality, and internet addiction among Hong Kong adolescents. BMC Pediatrics. 2016 Aug; 16(130).

[56] Lam L, Peng Z, Mai J, et al. Factors associated with internet addiction among adolescents. Cyberpsychology \& behavior. 2009; 12(5).

[57] Tekkant E, Topalglu M. The assessment of high schools internet addiction. Procedia -Social and Behavior Sciences. 2015; 205: 664-670. https://doi.org/10.1016/j.sbspro.2015.09.104

[58] Hawi N. Internet addiction test among adolescents in Lebanon. Computers in Human Behavior. 2012 May; 28(3): 1044-1053. https://doi.org/10.1016/j.chb.2012.01.007

[59] Jablonska B, Lindberg L. Risk behaviors, victimisation and mental distress among adolescents in different family structures. Soc Psychiatry Psychiatr Epidemiol. 2007; 42: 656-63. PMid:17522746 https ://doi .org/10.1007/s00127-007-0210-3

[60] Wang Y, Wu A, Lau J. The health belief model and number of peers with internet addiction as interrelated factors of Internet addiction among secondary school students in Hong Kong. BMC Public Health. Mar 2016; 16: 2-16.

[61] Shek D. Adolescents' perceptions of paternal and maternal parenting styles in a Chinese context. The Journal of Psychology Interdisciplinary and Applied. 1998; 132(5): 527-537. PMid:9729846 https ://doi.org/10.1080/00223989809599285 